\title{
The Missing God of Heidegger and Karl Jaspers: Too late for God; too Early for the Gods - with a vignette from Indian Philosophy
}

\author{
Purushottama Bilimoria ${ }^{1,2,3}$
}

Accepted: 11 August 2021 / Published online: 15 October 2021

(C) The Author(s), under exclusive licence to Springer Nature B.V. 2021

\begin{abstract}
The essay explores how God is conceived-if only just-in the works of two existentialist philosophers: Martin Heidegger and Karl Jaspers, one considers the mutual convergence and disarming divergence of their respective positions. In 1919, Martin Heidegger announced his distancing of himself from the Catholic faith, apparently liberating himself to pursue philosophical research unfettered by theological allegiances. Thereafter, the last of the Western metaphysicians (in the classical genre) takes his hammer to the 'destruktion of onto-theology' - the piety of Greek philosophy and of Hellenized Judaeo-Christianity. The essay argues that Heidegger provided both the platform and challenges reins for his long-time friend Karl Jaspers' thinking on the question of the absconditus - 'absconded into hiding; hence lost, or better, the missing condition' —of the transcendent. One might avail one's critical perspective by considering ideas from Indian philosophy (and mildly postcolonial doubt) to balance the respective positions of the two humanist-Germanic protagonists. We proceed so with a view to reconfiguring the predominant monotheistically conceived conception of the deity, the place and limits of belief and philosophical faith, and the future of postdivinism in the global axis.
\end{abstract}

Keywords Heidegger $\cdot$ Jaspers $\cdot$ Nothing $\cdot$ God $\cdot$ Gods $\cdot$ Devatās $\cdot$ Theism $\cdot$ Nontheism $\cdot$ Agnosticism $\cdot$ Philosophical faith $\cdot$ Indian philosophy

Made possible with support of Peoples' Friendship University of Russia (RUDN), Moscow, and Ministry of the Russian Federation (Reference No. 075-15-2021-603).

Paper presented at the Karl Jaspers Society of North America (KJSNA) Session at the World Congress of Philosophy in Athens, Greece, 2013; the unedited text was printed in the Brazilian Portuguese journal pragMATIZES - Revista Latino Americana de Estudos em Cultura, 2017, vol 7 no 3 http://www.pragmatizes.uff.br/index.php/ojs/article/view/175. The subreptive play on Heidegger's adage is explained at the end of essay.

Purushottama Bilimoria

p.bilimoria@unimelb.edu.au

Extended author information available on the last page of the article 
Vladimir: We're waiting for Godot.

Estragon: (despairingly) $A h$ !

Nothing happens, nobody comes, nobody goes, it's awful!

Vladimir: Let's wait and see what he says.

Estragon: Who?

Vladimir: Godot.

Estragon: Good idea.

Vladimir: Let's wait till we know exactly how we stand.

Estragon: On the other hand it might be better to strike the iron before it freezes.

('Waiting for Godot', Samuel Beckett)

\section{Martin Heidegger: Too Late for God}

Heidegger worried whether transcendence is comprehensible without any specific reference to God. What might be meant by 'transcendence' is the unfettered pursuit of the question of being and the quest for freedom and authenticity of being. This directive is consistent with the existentialist critique of Kantian and Cartesian metaphysics.

Karl Jaspers' pronouncement that at the root of existential philosophy-Existenzphilosophie - is an inscrutable mystery of Being, the 'Missing God,' that runs deeper than our conventional categories of theism, atheism, or agnosticism and may present itself as an alternative to the same quest that Heidegger underscored, but with significant difference in details and consequences. ${ }^{1}$

Heidegger is both inspiring and at the same time disturbing. After the 'Death of God' (the Nietzschean and Hegelian tropes), what remains? Is there room for theological existentialism of any sort? Heidegger here will be the hovering ghost; and for the perspective of Karl Jaspers, I shall be drawing from his 1951 lectures (which were broadcast) that include a section on 'The Idea of God.'

Here, I offer two contrary observations: (1) Heidegger, the last of the great metaphysicians, poses a radical and controversial challenge to philosophers by calling them to do without God in an unfettered pursuit of the question of being (through his 'destruktion of onto-theology' and his espousal of the metaphysic of non-being) and, (2) this exclusion nevertheless leaves room for a form of philosophical reflection on the religious, and the ensuing discourse concerning - not the God of philosophers as such, but rather-a notion of divinity in the experience of beings as beings, i.e., in a phenomenological mode (exemplified most clearly in Heidegger's 1920/1921 lectures on the phenomenology of religious life). ${ }^{3}$ This is congruent with Existentialism's attempt to find this ground from within the human form as the contextual whole through which a world appears.

\footnotetext{
${ }^{1}$ Nichol 2012; the specific cipher 'Missing God' arose in response to David Nichol in the seminar of the Karl Jaspers Society of North America (KJSNA) at the APA (American Philosophical Association) Pacific Division conference in Seattle (2012), as a more fitting rendering of deus absconditus in place of 'the unknown God' or even 'divine hiddenness.' See P. Bilimoria 2012.

2 Published as 'Karl Jaspers, The Way of Wisdom (1951)'.

${ }^{3}$ Issued as 'Martin Heidegger, The Phenomenology of Religious Life (2010)'.
} 
At the outset, I would like to simply state (as the argument has already been rehearsed in detail in a prior study $)^{4}$ that I believe that the notion of Nothingness is more important to Heidegger than the ancient or classical grand narrative of transcendence which he castigates as the Western (Judeo-Christian) mistake of what he calls onto-theo-logos. What he means is that all of Western metaphysics, and Christianity and Judaism - and we might add Islam — has a doctrine of Being qua presence, in contrast to a pre-Socratic understanding of Being qua absence and its concealment. What starts as Being fully present in Plato ends up as God in the Hellenized Testaments as fully present personal Being. ${ }^{5}$ Heidegger traces the initial (by no mentions historically first $)^{6}$ motivations in Plato's move to settle for an enduring transcendent form (eidos) that makes possible the making of things, that which is 'to be,' hence possessing beingness. Aristotle's science of 'on hēi on' sets out to investigate 'being as being,' its nature and qualities, etc., in an aporetic ontology of categories (Heidegger, 1929, 1993, 2-3). Neo-platonism seeks to transcendent being and non-being in the metaphysics of the One (to hen). In the next step, the distinction hedged between essence and existence in ancient thought is integrated in Thomas Aquinas' analogia entis suggesting a simulacrum of the divine in the creaturely beings and correlatively of finite entities with the divine 'subsistent being' (esse subsistens) (Heidegger, 1996, 4). In other words, as Heidegger notes: 'In medieval times, God became identified with the Being of entities and was depicted... as an all-powerful causal agent who planned, calculated, and produced 'the relatively stable and independent presence' of entities' (ibid). The larger the looming threat of non-being - even of the transient or contingent nature of beings - the more the effort to posit a substantive der Grund (groundholding) of permanence.

With Eckhart, Wolff, and Descartes, being takes an epistemological turn and becomes that which is indubitably cognizable as mind and Spirit-Being over the mechanical world. Though this tight hold is somewhat loosened with Kant-vide the non-presentification of the thing-in-itself-the focus shifts to conditions for the possibility of knowing Being in all its appearances and manifestations.

Now think of the short step also from Husserl's phenomenology of transcendence to Heidegger's ideal of Dasein (humanly be-ing there) making its own authentic existence as a supplement (complementum) out of the remnant possibilitatis suggested in Greek philosophy and after. Here, being - 'to be'-recalls, retrospectively, and portends, prospectively, its own noneist statis in the thrownness-unto-death, the great leveler of all actualizations. So 'what is there ("to be")?' for Heidegger becomes: 'What would its absence (nonabiding presence) be like ("to be not")?'.

\footnotetext{
${ }^{4}$ I discuss this in my recent paper 'Why is there Nothing rather than Something? An Essay in the Comparative Metaphysic of Non-Being,' for the Max Charlesworth Festschrift in Sophia, 51(4), 2012, 50930; slightly revised version in Bilimoria, (2019)

5 Perhaps Heidegger overlooked the impact of Zoroastrianism in the Middle East that followed the expanding Persian Empire, with its still somewhat crude form of monotheism with dualistic elements (eschewing polytheism which was the dominant trend in certain parts of the pre-axial world and continuing in India).

6 The Upanișads in India surely preceded Plato in the similar quest for the One (hence Brahman).
} 
Around 1919, Martin Heidegger writes to Engelbert Krebs, a Catholic priest and family friend, distancing himself from the Catholic faith of his youth. He no longer wished to be thought of as a Catholic philosopher but simply as a philosopher, free to pursue his philosophical research unfettered by extra-philosophical allegiances.

However, the lectures on St. Paul, and on St. Augustine especially, show that in the early 1920s, Heidegger had not yet lost sight of the philosophical potency of the standpoint of faith. By the time of writing Being and Time, however, his judgment had hardened, and the matter had been settled. While he clearly maintained his regard for theology and even entertained hopes for its revival as a discipline, he had reached the decisive verdict: Genuine philosophy cannot take root in the soil of faith. And yet he was opposed to its polar opposite in humanism or the humanist project of the kind that the French existentialists, especially Sartre, took up.

The question then arises: Is transcendence-that is characteristic of being-in-theworld-comprehensible without reference to God? Could it even be that the most profound questioning of Heidegger's own thinking is sustained by a disavowed relation to the deus absconditus, a divine interlocutor for whom the 'impossible possibility' of death was only ever a weak substitution? And might that not remain a radical philosophical potentiality within the standpoint of what philosophers of religion today call 'propositional faith' (as distinct from belief) despite Heidegger's disapprobation of faith—or was it abstract belief — as the mortal enemy of philosophical thought?

But faith, and transcendence on which it is pivoted, do not escape the chaos and snares of contingency: How could it if its non-finiteness is not affirmed? It causes disruption, dislocation, and disfiguring; the Buddhist Chandrakīrti (ninth century CE) confessed to this.

Heidegger's thinking on non-being - the Nothing-is nowhere more saliently and forcefully presented than in his inaugural lectures of 1929 when he succeeds his teacher Edmund Husserl in Freiburg University (delivered to the faculty in the grand auditorium), entitled Was ist Metaphysik? (just two years later than Being \& Time, 1927). He complains that science only examines beings, and nothing further; it rejects 'nothing' read as 'not-ing' and 'nullity' (das Nicht), as a 'phantasm' (1993, 95-96). And thus he pleads (to the chagrin of Carnap who elsewhere comments on this passage):

What should be examined are beings only, and besides that-nothing; beings alone, and further-nothing; solely beings, and beyond that-nothing. What about this nothing?...Is the nothing given only because the 'not', i.e., negation, is given? Or is it the other way around? Are negation and the 'not' given only because the nothing is given?...We assert that the nothing is more original than the 'not' and negation...

Where shall we seek the nothing? Where will we find the nothing?...[W]e do know the nothing...Anxiety reveals the nothing...that in the face of which and for which we were anxious was 'really' —nothing. Indeed: the nothing itselfas such-was there... How is it with the nothing?... The nothing itself nihilates. (Heidegger, 1929, 1993, 95-6).

So mired with God as Being rather than the sum-total of all being/s, Christian dogma, he proceeds to tells us, denies the truth of the proposition ex nihilo nihil fit 
and gives a twist to the meaning of Nothing, so that it now comes to mean the absolute absence of all 'being' outside of God's existence: ex nihilo fit-ens creatum-the created being is made out of nothing. 'Nothing' is now the conceptual opposite of what truly and authentically 'is'; it becomes the summum ens, God as enin-creatum.

Here, too, the interpretation of Nothing points to the fundamental concept of whatis. In both cases, the questions concerning Being (Sein) and Nothing as such remain unasked. Hence, we need not be worried by the difficulty that if God creates 'out of nothing,' he above all must be able to relate himself to Nothing. But if God is God, he cannot know Nothing, assuming that the 'Absolute' excludes itself from all nullity. Not wishing to lose sight of the work of Being, Heidegger reformulates the old proposition 'ex nihilo nihil fit' so that it runs thus: 'ex nihilo omne ens qua. ens fit: every being, so far as it is a being, is made out of nothing, Only in the Nothingness of Da-Sein can what-is-in totality...come to itself.' (This is the motif that perhaps inspired Sartre, who some say stole the wind from Heidegger's sails, and dubbed his own magnum opus, 'Being and Nothingness': what else could there be if Being is erased?)

Contrary to general perception, Heidegger's ontology is not one of Nothingness as such; he is not a nihilist, far from it (he distances himself from a 'Philosophy of Nothing' in the Postscript); rather, Being as Da-Sein remains very much the subject and project of metaphysics, and of theology too if you will. This latter emphasis takes us to Karl Jaspers, who was both Heidegger's friend and his bête noire. ${ }^{7}$

To conclude this section of the discussion, according to Heidegger, Nietzsche's adage 'God is Dead' brings to philosophical awareness a profound event that has occurred and is occurring in the history of the West; and his interpretation of this famous adage of Nietzsche becomes, from the mid-1930s, a persistent reference point for his discussion of the contemporary age as well as his discussion of the task of thinking (Heidegger, 1977). It points the way to the properly philosophical mode of being and thinking. Yet, for all this - and in contradistinction to Nietzsche-Heidegger steadfastly refuses to tell us whether or not to continue with belief in God. As the philosopher, Heidegger (somewhat reminiscent of the Buddha in the Indic-Brāhmaṇic ambience) steadfastly abstains from pronouncing on the question of God; and this means abstaining from any kind of doxastic stance, whether it be positive (God exists), negative (God does not exist), or undecided (I do not know whether God exists). Heidegger's philosophy, therefore, cannot be properly described as theistic, atheistic, or for that matter agnostic (as Jaspers poignantly pointed out); it suspends all doxastic attitudes. Its atheism is methodological. This theological epoché might even be central enough to Heidegger's view of philosophy for us to regard it as the decisive component of his philosophical method. In any case, the main point here is to appreciate that for Heidegger, from at least as early as 1921, such an abstention is understood to be a condition for the possibility of philosophical inquiry or thinking in his strict sense of the term.

\footnotetext{
$\overline{7}$ See David Farrell Krell (1978).
} 


\section{Jaspers: the Idea of God}

Karl Jaspers, with whom Heidegger maintained a close relation as a friend and colleague (until the latter's dubious and politically catastrophic involvement with National Socialism), explains in his 1951 broadcast on 'The Idea of God', that while Western theology and philosophy have reflected on Who or what is God?

$[\mathrm{M}]$ ost philosophers of our times seem to evade the question of whether God exists. Among those who confront it, some philosophers offer logical proofs for the existence of God, while others argue that if all proofs of the existence of God can be refuted, then there is no God. Jaspers rejects both of these positions, and argues that the existence of God can neither be proved nor can it be disproved in logic or language. The supposed proofs and disproofs of God's existence treat God as an object and are therefore invalid. These proofs and disproofs are only attempts to achieve subjective certainty through the use of fallacious modes of reasoning. ${ }^{8}$

Is God dead then? Well, not quite. According to Jaspers, we cannot make God an object of our knowledge. Still, even if we admit that we cannot know God, it doesn't follow that we cease to philosophize or throw up our arms with the disclaimer: It is best not to talk of what we do not know, as we do not know which things we do not know. ${ }^{9}$

Hence, he takes up the oldest form of inferential proof for the existence of God: the cosmological argument. Rather than refuting the argument, Jaspers looks upon it to derive a metaphorical epigram; and this is what he curiously adduces:

... [T] This notion takes on a new meaning when it is no longer regarded as a proof. Then metaphorically, in the form of an inference, it expresses awareness of the mystery inherent in the existence of the world and of ourselves in it. If we venture the thought that there might be nothing, and ask with Schelling: Why is there something and not nothing? we find that our certainty of existence is such that though we cannot determine the reason for it we are led by it to the Comprehensive, which by this very essence is and cannot not be, and through which everything else is. (Ibid, 43).

\footnotetext{
${ }^{8}$ In published version 1954, 42-43. Reproduced in commentary form Alex Scott (2002). https://www. angelfire.com/md2/timewarp/jaspers.html

9 Although in modern times, something close to this double disavowal is attributed to Donald Rumsfeld, a former Congressman and US Defense Secretary (in the quaint form: 'But there are also unknown unknowns - the ones we don't know we don't know'), it could be argued that Indian theory of avidya (nescience, ignorance) had come to a similar conclusion in that in our supposed oblivion or amnesic state that we suffer from within the contingent, repetitive, existence, we are blissfully ignorant of things we don't even know that we do not know, i.e., we don't know what are the right questions to ask. To give a contemporary instance, while there are many things about the COVID-19 condition and the virus that causes this infection in rapid mutations that we don't know, and we know that we don't know; indeed, it may well be the deniers - of COVID19 as well as of climate change and science-don't know that they don't know (and will probably never bring themselves to know, because they have removed themselves two-fold from the truth of the matter).
} 
Jaspers next ponders if our reflection on the world of things, which doubtless is beautiful, can lead us to an inference such as of the invisible hand of a grand designer. To this, he makes the following response:

But if from all this abounding mystery we infer that God, the benevolent creator, exists, we must call to mind all that is ugly, disordered, base in the world. And this gives rise to fundamental attitudes for which the world is alien, frightening, terrible, and it seems as plausible to infer the existence of the devil as of God. The mystery of transcendence is not thereby solved but merely grows deeper.

But what clinches the matter is the imperfectibility of the world. The world is not finished, but in continuous change; our knowledge of the world cannot be completed, the world cannot be apprehended through itself.

Far from proving the existence of God, these so-called proofs mislead us into placing God within the real world, or second cosmos, which is as it were ascertained at the limits of the cosmos. Thus they obscure the idea of God. (Ibid, 44).

Jaspers echoes here a return to Heidegger's Nothingness and, despite medieval theologians, dilates on the starkly imperfect nature of the world:

But they move us deeply when, leading through the concrete phenomena of the cosmos, they confront Nothingness and imperfectibility. For then they seem to admonish us not to content ourselves with the world as the sole meaning of our life in the world. (loc cit).

So yes, it is true, Jaspers argues, we cannot know God; God is incomprehensible; but we can have a modicum of belief in God. We can have or entertain belief as distinct from knowledge; however, belief in God may well call for faith. ${ }^{10}$ What though warrants this call to faith, what is the source of faith, and what kind of epistemé is this? Does it have its loci in reason, cognition, clear light of mind, or the intellect, or is its radiance to be found elsewhere? Well, Jaspers asserts at this point, which might be disappointing to a deeply thinking philosopher, that 'Freedom' (etymologically, free from judgment or fate, dom $)^{11}$ is the source of faith, and our freedom comes from God. True awareness of freedom produces certainty of the existence of God.

\footnotetext{
10 Scott, op cit.

11 Passing, rather obscure, reference to the optimal freedom in the states of nirvāna and mokṣa is made. One might also be reminded of the soul-blues lyrics by Eric Bibb-

Don't Ever Let Nobody Drag Your Spirit Down...

Remember we walking up to heaven.

Don't let nobody turn you 'round. (1950).

or the counterfactual:

Freedom, freedom.

Sometimes I feel like a motherless child.

Sometime I feel like I'm almost gone.

A long way from my home.

Richie Havens (1969).

(Blues by the Bay, www.kpfa.com).

'There is no freedom without justice and peace,' Stride Toward Freedom, Martin Luther King Jr., 1958, 2017.
} 
Indeed, faith in God is not the same as knowledge of God, but we may gain a clarity of insight through philosophy which may enable us to have a comprehensive consciousness of God. Jaspers goes onto to argue that in 'boundary situations,' we may perceive either Being or Nothingness. And he further argues that the concept of human freedom without God, in which the will to make free choices is perceived as if it were independent of God, exemplifies the angst/anguish (using a term from Kierkegaard) of the facticity of Nothingness.

If we acknowledge that we depend on God for our being, and if we accept responsibility for making our own free choices, then our awareness of our own freedom becomes an awareness of God. ${ }^{12}$

However, one wonders how can Jaspers be so certain that in perceiving or introspecting the phenomenology of our own freedom, we can arrive at a certitude about the being of God? Heidegger chided Jaspers precisely on this sort of claim as smacking of extreme subjectivism, a veritable misinterpretation of phenomenology, even as one stoops to the lure of grandiose transcendentalism. Let us press on with the discussion on faith, with a question.

Is this the same faith as that of the religious, sectarian, and evangelical adepts? That is, does Jaspers mean to collapse the conditions for the possibility of philosophical awareness of the divine with religious and theological faith? Faith in Jaspers' philosophical thinking is a category that stands squarely within the pure conceptual-metaphysical schema and only just touches the borders of the spiritual, albeit via Nothingness, which it must overcome in ontology not in as it were the heart as such. Let me go on with this and develop a critical background from contemporary philosophy of religion and some cross-cultural refractions that will help unpack Jaspers' thinking on this matter.

First up, there is an epistemological question of how much more weight can we give to 'faith' vis-à-vis belief. By a twist of faith, Jaspers collapses the two. Surely, we reduce whole junks of knowledge claims to beliefs and represent these in propositions and sentences and then begin to interrogate or connect them logically with other sets of beliefs for their coherence, correspondence with reality, and so on. In the old-style philosophical theology, 'faith' belonged to matters religious, a religious way of life, commitment to ultimate values and some ultimate inexplicable and ineffable reality. Faith in that sense would be personal, even a matter of feeling, emotions, evocation, and subjective disposition, and it has the most tangential connection with the proposition and thought in which it might be articulated and expressed, but not necessarily so. 'Belief' just might be tagged onto it as we assign labels to certain select messages in our overflowing inbox. In other words, we may do this in deference to ersatz folk psychology but not in strict philosophical thinking, unless we are prepared to subject the contents of the belief which is a disposition to form thought or concepts to rational scrutiny and the criteria of justified true belief or unjustified false belief, where faith as portending some kind of possibility might just linger.

God is not what we may see with our eyes, not as factual elements of a deity, but as symbolic ciphers of human possibility, or symbols of transcendence, as the

${ }^{12}$ Ibid. 
human existential possibility of inner change, reversal, and transformation. Wherever this cipher is hypostatically defined as mere positive fact of belief, he concluded, however, that the freedom of transcendence obtained through the sympathetic interpretation and recuperation of this cipher is obstructed. Jaspers beholds the same transcendental thrust in world philosophies across the axial civilizations ${ }^{13}$ as well, which he articulates in volume I of the tome The Great Philosophers, entitled, 'Socrates, Buddha, Confucius Jesus,' and to that metaphysical galaxy, he adds Lao-tse, Mencius, Chuang-tse, Ashoka, and Nāgārjuna. These great individuals and thinkers, he avers, connect us to the depth of the transcendence, to moral resolve, to seeing substance in the world, and to clarity of knowledge, but also to the tragic in the lebenswelt. ${ }^{14}$

\section{Indian Philosophical Response: Too early for the Gods}

Many cultures have struggled with the same questions and hit upon the sense of the tragic, radical tragedy if you will. We note in passing the empathic ruminations on the carnage wrought by the great war in the Indian epic The Mahäbhärata; one might cite Gautama the Buddha who was profoundly overcome by the pervasiveness of suffering (duhkha) in the world. Indeed, there were Confucius, the Taoists, and going back further in the Indian tradition, the Rgvedic bards in their unsettling angst attempting to ascertain whether the gods had not cursed humanity to bear pain and depravation for all eternity. But why and how is it that almost none eschewed or skipped the possibility of transcendental access, even if theism (i.e., the belief in the grace and benevolence of a personal Omni-God) was not available or not accepted (e.g., by Confucius, the Buddha, Nāgārjuna, the Jainas, and the Mīmāmsāa and Sāmkhya, two prominent atheistic schools within Hinduism)? Will a time come for a civilization when tragic knowledge no longer suffices as the ultimate expression of deliverance (Bilimoria, 2012, 43)? This explains why world saviours such as Jesus, Mahāvīra, or the Buddha, Mohammad [pbu], and Guru Nanak offer messages of universal liberation for humanity. Theism is not a universal project or narrative, and it need not to be the kingpin for the wheel of samsāra either; hence, for that reason alone, theism need not to be the bugbear of religious existentialism. I think Jaspers comes close to this global sensibility; his insights here, not far from Heidegger's, come closer in kind if not in intent to that which we might discern from a broader historical archaeology of human existential experiences, the tragic and the aesthetic.

A Jasperian might argue that strictly within the historical perspective, the radical atheistic solution is but a small drop in the ocean, a slice within the history

\footnotetext{
13 The Axial Period is the span of 600 years from $800-200 \mathrm{BCE}$ when there is a historical shift in the world towards the teleological or spiritual evolution of the human species, and this is demonstrated in the rise of the Buddha, Zarathustra, Confucius, Pythagoras, and Jesus following a number of Hebrew prophets (Karl Jaspers, 1953). We should mention here the ancient Kojiki sect in pre-Tokagawa Japan, mitigated later by Neo-Confucian influence, in their concept of tama-musuhi (musubi no mi-tama) with its worship of ancestral deities; See Bilimoria (2013).

14 See special issue of Existenz, Introduction to The Great Philosophers Karl Jaspers 1883-1969, 12 (1) Spring 2017, 2, 9, 43; https://existenz.us/volumes/Vol.12-1
} 
of human evolution (not in biological terms but in terms of the development of consciousness and the political). Or as Charles Taylor (2007) has shown in his monumental work, modernity (including early stages of post-modernity) and secularism - the Age of the Secular-has a great deal to do with this; the pressure of the scientific age, the suspicious marginalization of the sacred because of the excesses of the church and Christendom, forced the post-enlightened sensibilities (in the plural) to take cover under anything but the sacred heretofore. It is a particularly Western response in the coming age of technology, the culture of techno-science as Heidegger also asked. Taylor, by the way, thinks that a society would be deemed secular qua secularity or not, 'in virtue of the conditions of experience and search for the spiritual' (ibid, 20); and as David Nichols (2012, 37) points out rightly in my reading, "whether existentialists fall into "theistic" or "atheistic" [or "agnostic"] camps, they share this much in common, [namely,] a rejection of the God of Western metaphysics.' 15

Neither God nor religion is the specific preserve of the West. Conventional philosophy of religion and religious studies as practiced mostly in Western academies are centered on the notion that the phenomenon called 'religion' has been constitutive of the philosophical and cultural frame of the West; religions in the rest of the world are of interest, as Kant also believed, for an anthropological and ethnographic perspective on the 'other.' A truly global-critical philosophy of religion would seek to undo this bias, perhaps even overturn the assumptions on their head.

And indeed, as the editors of this special issue note in their Introduction citing Michael Martin, certain forms of atheism can have strands of the religious or spiritual within them; the existentialist philosopher, Robert C. Solomon (2002), had argued for a kind of spirituality for the skeptic (whom he took to be largely atheistic, if not at least non-theistic). Besides, it is difficult to place pantheism and panentheism, even henotheism or a theistic-monism (as in the Hindu Bhavagadgit $\bar{a}$ ), squarely within the fold of theism as these do not 'progress or evolve' (in R. C Zaehner's sense) towards monotheism, which is really the target of the atheistsand not the 'softer' forms of theism-as we have shown Jaspers to be at pains to point out.

Even within predominantly theistic (again, in the sense broader than monotheistic) traditions, there can be strands of atheism (or its variations in a/theism, non-theism) that sit comfortably alongside each other. They could even be in some dependent relation —as in the case of the Mīmāṃsā within the Brāhmaṇical smoky maṇdapa (canonical canopy). This is so because it is the Mīmāmsā that provides the bedrock argument for the Vedas (preeminent scriptures) being authorless (apauruṣeya, and therefore perennial). This rejection of God by the Mīmāmsā scholastics is intended to block any attribution of possible authorship of the Vedas to one supreme deity (Bilimoria, 1989, 2001); yet at the same time, the devatās, gods, are needed as functionaries, or remote agencies, to help bring to fruition expected

\footnotetext{
15 See also Raphael Lataster, The Case Against Theism Why the Evidence Disproves God's Existence, Dordrecht: Springer, 2017.
} 
results from the illocutionary performance of mantras and obligatory sacrificial rites, albeit with a deontic disposition. The Mīmāṃsā would object to being categorized as atheistic in the same sense in which secular atheism (especially postenlightenment) may be described, because the Mīmāṃsā still has belief in-albeit effervescent, hence devatā-reality of the kindred of Greek gods whom Heidegger did not completely abandon either (Bilimoria, 2021a).

Elements of reverential veneration tantamount to personal worship are present in both Jaina and Buddhist religions as well; if they were so fully atheistic, why have they been considered part or pillars of World Religions, and only lately of World Philosophies? ${ }^{16}$ Worship may also include forms of supplication generally called prayer; but the question arises whether atheists (in the modern Western framing) should excuse themselves and never engage in prayer or participate with full intent in prayers (other than a collegial or family-friendly gesture of tolerantly sitting through them-as for example at a religious funerary rite such as Jewish Shiva or the wedding ceremony of a devout couplebut without undergoing the requisite preparations, such as fasting and refraining from alcohol consumption for certain days prior to the event). It would be interesting to ask: Do the agnostic, non-theist, and even atheist have an obligation to pray? John Caputo (1997), John Lemos (1998), and Travis Dumsday (2012) believe they do, answering for each. The case gets stronger as COVID-19 and an increase in death by cancer, hunger, homelessness, and climate change are being witnessed all around the world (the otherwise privileged 'First World' included). God might have 'been and gone,' as my good friend and colleague Patrick Hutchings puts it in his elegant article in this special issue of the journal; but we say the need for empathic supplication and prayer may not have gone away with the absconding or absent Almighty. That is precisely why the subtitle 'Too Late for God, Too Early for the Gods' of this discussion is a subreptive play (in the sense of reversal) on Heidegger's adage: 'Too late for the gods; too early for God.' 17

\section{Conclusion}

Heidegger's Letter on Humanism (1946) invites us to reconsider the divine in the light of an ontological difference between Being and beings. Both Jaspers and Heidegger take their theological cues from the standpoint of the 'missing God,' where God necessarily remains hidden, a self-concealing source for all appearances. For this, an ecstatic quest for the concept of 'God' in the description of human existence, and more generally in our experience of presence and absence,

\footnotetext{
16 See Ninian Smart, 1999; http://www.jainpedia.org/resources/search.html?tx_solr\%5Bq\%5D=worsh ip\&id $=813 \& \mathrm{~L}=0$.

17 See also study of Heidegger's interest in and overlaps with Indian thought, plus conversations with his Indian philosopher friend, J L Mehta, and Wilhelm Halbass on both: Bilimoria (2021a, b; 2001) and Jackson (1993).
} 
is argued for. And this is a veritable contrast to the approach that pivots human experience on tragedy, absurdity, meaningless, and Angst; although we might add, the quest may begin here but need not end thus. 'The poet or mythmaker supplies us with the earliest responses to wonder by describing the essences as deities' (Ibid). Textual history of a few non-Western traditions might underscore that better (e.g., Bilimoria, 2013, 2021a).

Jaspers kept a book of critical notes on Heidegger, and he routinely described Heidegger's fundamental ontology in a tone of moral-humanistic disapprobation; yet a common sentiment shared by Heidegger and Jaspers is that transcendence can intrude (that is, be something of an intrusion) in human consciousness, albeit as an experience of the absolute insufficiency of this consciousness for the task of interpreting its own originary or metaphysical character. Historically speaking, we are at the apotheosis of a crisis in transcendence, i.e., a crisis of the metaphysics of consciousness.

Jaspers' own metaphysics is always a 'post-Kantian metaphysic': It is a negative metaphysics. As such, it resists all the proposition that human reason might afford itself an account of metaphysical essences. That is turn would define the realm of human meaning formed by its difference against positive metaphysical knowledge, but which nonetheless sees reason, in the Kierkegaardian manner, as driven by a despairing desire for metaphysical transcendence. In this respect, I venture to suggest that Jaspers, on the coattails of Heidegger who himself is haunted by Hölderlin, anticipates the kinds of move we have seen arise toward the end of the twentieth century in critical philosophy of religion, such as 'reasonable unbelief' (not to be confused with 'rational disbelief') wherein seekers have exhausted all possible arguments that might provide them with any convincing ground for believing. ${ }^{18}$

And as to faith, I have argued that since the Enlightenment, the Disenchantment, and the Secular Age, there has always been a question about the promises and future of faith, albeit until then understood mostly as a religious prerogative or theological proclivity, a spiritual, even transcendental, or metaphysical alignment, and not as such as a proper philosophical disposition. In a sense, as I have shown, Jaspers is fully aware of the near impossibility of the return of an unrequited faith any more than a fully embraced return of religion unlike that of the pre-Enlightenment era. Nonetheless, I believe that Jaspers is well placed just on the edge of Enlightenment, in which space faith, even if just a modicum of it, has not vanished from humanity's quest for transcendence. While there is still a seeking to be anchored in the challenging realities of existence and Nothingness, one has to recognize this as being at once a clever and a cunning move. And to be sure, there are saints and martyrs of philosophical faith to the east of Athens and Rome-as Jaspers demonstrate in his recurrent extensive references to the Buddha, Confucius, and Lao-Tzu, among others, as exemplary philosophers of faith (or if I may risk a parody: All Souls of the Faithful Unbelievers). Even the irenic Socrates, the social Jesus, the reformist

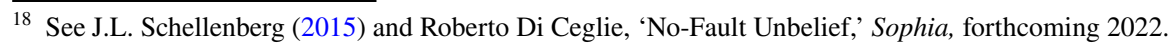


Mohammad, and a resistant Gandhi were each engaged in communicative solidarity and philosophical faith of sort. ${ }^{19}$ It is perhaps not humanism, nor posthumanism, or postmodernism (interlooped to postcolonialism), but in the expectant postdivinism, with its onward march backwards from the future, to which we might look and upon which we await in effable silence.

Acknowledgements I wish to express gratitude to participants at the Karl Jaspers Society of North America (KJSNA) Session in World Congress of Philosophy in Athens, Greece (2013), for their critical comments and to an anonymous reviewer for Sophia, and also Colette Walker for earnest editorial help. I dedicate this work to Prof. J. N. Mohanty who taught me Phenomenology and Heidegger, and to Patrick Hutchings who taught me to doubt, and entertain reasonable unbelief, with a modicum of philosophical mischief.

\section{References}

Bilimoria, P. (1989). The idea of Authorless Revelation (Apauruṣeya). In R. W. Perrett (Ed.), Indian Philosophy of Religion (pp. 143-166). Martinus Nijhoff/Kluwer Academic Publishers.

Bilimoria, P. (2001). Hindu doubts about God: Towards a Mīmāṃsā deconstruction. In R. W. Perret (Ed.), Philosophy of Religion (pp. 87-106). Garland Publishing Inc.

Bilimoria, P. (2012). Comments on David Nichols: 'The God of the existentialist philosophers'. Existenz, $7(2), 52-56$.

Bilimoria, P. (2013). Tomoko Iwasawa's Tama in Japanese Myth. Existenz an International Journal in Philosophy, Religion, Politics and the Arts, 7(2), 15-20.

Bilimoria, P. (2019). 'Why is there Nothing rather than Something?' An Essay in the Comparative Metaphysics of Non-Being. In P. Wong, S. Bloor, P. Hutchings, \& P. Bilimoria (Eds.), Considering Religions, Rights and Bioethics: For Max Charlesworth (pp. 79-197). Sophia Studies in Cross-cultural Philosophy of Traditions (Series). Springer.

Bilimoria, P. (2021a). Māntric effect, effervescent devatā-s, noetic supplications, and apūrva in the Mīmāṃsā. In R. D. Sherma \& P. Bilimoria (Eds.), Contemplative Studies and Hinduism Meditation, Devotion, Prayer, and Worship (pp. 178-194). Routledge.

Bilimoria, P. (2021b). After Comparative Philosophy: Discussion of "Wilhelm Halbfass and the Purposes of Cross-Cultural Dialogue,” by Dimitry Shevchenko'. Philosophy East \& West, 7(3), 815-829.

Caputo, J. (1997). The Prayers and Tears of Jacques Derrida: Religion without religion. Indiana University Press.

Di Ceglie, R. (2022). 'No-fault unbelief', Sophia, forthcoming.

Dumsday, T. (2012). Why (most) atheists have a duty to pray. Sophia, 51(1), 59-70.

Heidegger, M. (1929). Was ist Metaphysik? F. Cohen Verlag.

Heidegger, M. (1993). What is metaphysics? In D. F. Krell (Ed.), Basic Writings (pp. 89-110). HarperCollins.

Heidegger, M. (1996). Being and Time (Sein und Zeit), Joan Stambaugh trans. SUNY Press.

Heidegger, M. (1946, 1978). Letter on Humanism. In D. F. Krell (Ed.), Basic Writings: Nine Key Essays, plus the Introduction to Being and Time, trans (p. 208). Routledge.

Heidegger, M. (1977). The Word of Nietzsche: 'God is Dead'. In W. Lovitt (Ed.), The Question Concerning Technology and Other Essays, trans (pp. 53-112) Harper \& Row.

Heidegger, M. (2010). The phenomenology of religious life. Translated by Matthias Fritsch and Jennifer Anna Gosetti-Ferencei. Indiana University Press.

Jackson, W. (1993). J L Mehta on Heidegger, Hermeneutics and the Indian Tradition. E J Brill.

\footnotetext{
19 From author's seminar essay 'Philosophical Humanity and the Future of Faith,' being a response to the book, H. Wautischer et al. (eds) (2012), Philosophical Faith and the Future of Humanity, at the Karl Jaspers Society of North America (KJSNA) Session, APA (American Philosophical Association), Pacific Division, San Francisco, April 2013.
} 
Jaspers, K. (1951). 'The idea of God' Broadcast Lectures. q.v. Jaspers, 1954; Scott, 2002.

Jaspers, K. (1953). The axial period. The Origin and Goal of History (pp. 1-21). Yale University Press.

Jaspers, K. (1954). Way to Wisdom: An introduction to philosophy, translated by Ralph Manheim. New Haven: Yale University Press. (reprints 1960, 1964, 2003).

Jaspers, K. (2010). Way to wisdom: An introduction to philosophy, http://www.archive.org/stream/wayto wisdomintro00jasp/waytowisdomintro00jasp_djvu.txt. Accessed 11 Sept 2021.

King Jr. Martin Luther. (1958, 2017). My pilgrimage to nonviolence on Gandhi's legacy (based on Stride Toward Freedom) (Edited with Introduction by Clay Carlson). Beacon Press.

Krell, D. F. (1978). The Heidegger-Jaspers relationship. Journal of the British Society for Phenomenology, 9(2), 126-129.

Lemos, J. (1998). An agnostic defence of obligatory prayer. Sophia, 37(2), 70-87.

Nichols, D. P. (2012). The God of the existentialist philosophers: Fate, freedom, and the mystery. Existenz, 7(2), 36-44.

Schellenberg, J. L. (2015). The Hiddenness Argument: Philosophy's new challenge to belief in God. Oxford University Press.

Scott, A. (2002). Karl Jaspers's Way to Wisdom. https://www.angelfire.com/md2/timewarp/jaspers.html. Accessed 1 Sept 2021.

Smart, N. (1999). Dimensions of the sacred: An anatomy of the world's beliefs. University of California Press.

Solomon, R. C. (2002). Spirituality for the skeptic. Oxford University Press.

Taylor, C. (2007). A Secular Age. Belknap Press of Harvard University Press.

Wautischer, H., Olson, A. M., Walters, G. J. (2012). Philosophical faith and the future of humanity. Springer.

Publisher's Note Springer Nature remains neutral with regard to jurisdictional claims in published maps and institutional affiliations.

\section{Authors and Affiliations}

\section{Purushottama Bilimoria ${ }^{1,2,3}$}

1 School of Historical and Philosophical Studies, University of Melbourne, Melbourne, Australia

2 Indian Philosophy, RUDN University, Moscow, Russia

3 San Francisco State University, San Francisco, CA, USA 